\title{
Nitrates in Groundwater of Small Shallow Aquifers in the Western Side of Hoya de Huesca (NE Spain)
}

\author{
Raquel Zufiaurre ${ }^{1}$, Pablo Martín-Ramos 2,3 and José Antonio Cuchí ${ }^{2, *(1)}$ \\ 1 Departamento de Química Analítica, Escuela Politécnica Superior, Universidad de Zaragoza, Carretera de \\ Cuarte s/n, 22071 Huesca, Spain; zufi@unizar.es \\ 2 Departamento de Ciencias Agrarias y del Medio Natural, Escuela Politécnica Superior, \\ Universidad de Zaragoza, Carretera de Cuarte s/n, 22071 Huesca, Spain; pmr@unizar.es \\ 3 Instituto Universitario de Investigación en Ciencias Ambientales de Aragón (IUCA), \\ Universidad de Zaragoza, 50009 Zaragoza, Spain \\ * Correspondence: cuchi@unizar.es; Tel.: +34-974-239-338
}

Received: 2 December 2019; Accepted: 20 December 2019; Published: 22 December 2019

\begin{abstract}
Nitrate is one of the most common groundwater contaminants in rural areas. In this work, the presence of high levels of nitrate in groundwater of the aquifers of the west part of Hoya de Huesca County (NE Spain) has been studied by coupling hydrogeological information with water sampling techniques through a wide areal sampling of 90 surface water and groundwater points belonging to several aquifers. The results showed a general hydrochemistry of calcium carbonate to calcium sulfate waters. Unlike other case studies in Mediterranean areas, in which nitrate pollution was associated with irrigated crops, the highest concentrations in the present study were found in dry farming areas in which winter cereal is grown. A monthly nitrate level monitoring, conducted in 21 selected points between 2016 and 2017, showed that the nitrate evolution pattern followed the $\mathrm{N}$ fertilizer application schedules in the sampling points in which the highest concentrations were recorded, whereas an annual regularity could be observed in the sampling points with low nitrate levels. The compilation of data for 16 selected points since 1990 shows that the problem is persistent and points to the need of implementing new aquifer pollution control measures, since the ones currently in force have not been successful.
\end{abstract}

Keywords: diffuse pollution; dry farming agriculture; nitrogen fertilization; Pre-Pyrenees; vulnerable aquifer

\section{Introduction}

Artificial nitrogen fertilization is one of the pillars of modern agriculture. However, it is widely recognized that its uptake by the roots of the crops features a medium-low efficiency, in spite of valuable research efforts aimed at improving the efficiency of the agricultural management of $\mathrm{N}$ fertilizers, manure, and crop residues [1-6]. Consequently, the leaching of nitrogen species from soils to aquifers represents one of the main environmental problems associated with agriculture.

The non-natural presence of high levels of $\mathrm{N}$ species in groundwater $(\mathrm{GW})$ is a matter of concern in many irrigated and non-irrigated agricultural regions of the world [7-10], including Europe [11-13]. This issue is considered a serious threat to GW quality [14] and has resulted in the promulgation of two European Union directives to address the problem: Council Directive 91/676/EEC [15], which establishes that both surface freshwater and groundwater can be considered affected by nitrate pollution when they contain, or could potentially contain, more than $50 \mathrm{mg} \cdot \mathrm{L}^{-1}$ of nitrate; and Directive 2000/60/EC [16], which establishes a recommended limit for nitrate in drinking water and for the eutrophication of freshwaters of $25 \mathrm{mg} \cdot \mathrm{L}^{-1}$. 
Nitrogen pollution is also widespread in Spain, where high $\mathrm{N}$ concentrations, mainly nitrates, have been detected in several areas [17-21], which include the Autonomous Community of Aragón, located at the middle Ebro Valley, an important agricultural area in the northeast (NE) of Spain [22,23].

Since the end of the 20th century, high values of nitrates have been reported in the GW of several points in the west part of Hoya de Huesca County, located at the southern side of the Pyrenees range (Figure 1). This led to the declaration of an important part of the county as vulnerable to water pollution by nitrates from agricultural sources by the Agricultural Department of the regional government (Dirección General de Aragón, DGA) [24].

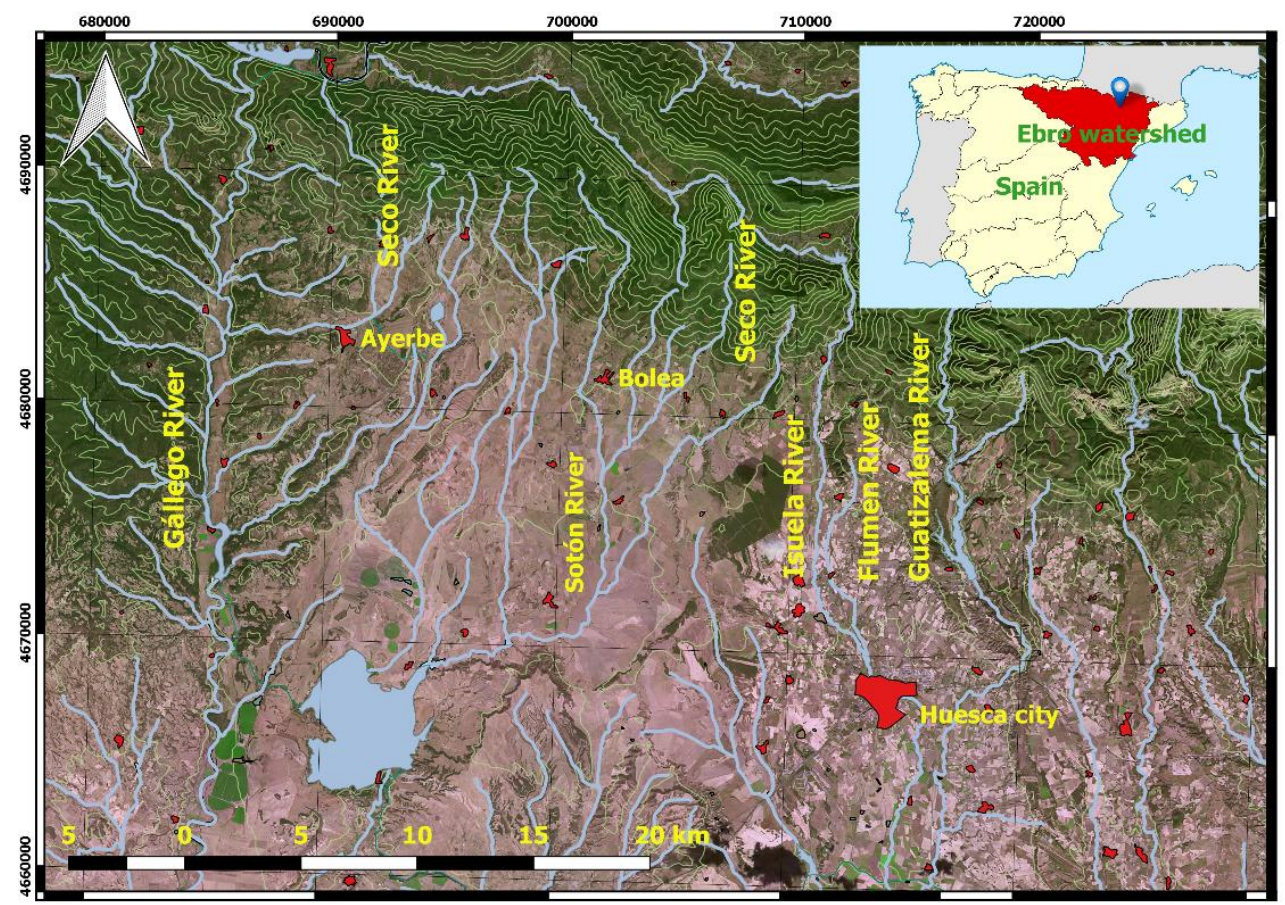

Figure 1. Location of the area of study, in the west part of Hoya de Huesca County. Urban areas are shown in red. The inset in the upper right corner shows the location of Ebro watershed in Spain.

In this context, the University of Zaragoza has been conducting a series of studies since 1994 [25-29] to monitor the contents of nitrates and other ions in the GW of several small aquifers in the agricultural area of Hoya de Huesca County. The paper presented herein summarizes the main results for several small aquifers, in which the spatial and temporal nitrate pollution has been investigated. The aim of the study is to recognize the origin of nitrate pollution and to gain insight into the relationships between land use, extension, intensity, and duration of the problem.

\section{Materials and Methods}

\subsection{Area of Study}

The area of study (Figure 1) is located in the western side of Hoya de Huesca County, at the northern side of the Ebro Valley (NE of Spain). The area comprises part of the southern foothills of the Aragonese Pre-Pyrenees and the plains between the Gállego and Flumen rivers, left-bank tributaries of the Ebro River.

The western side of Hoya de Huesca County is divided into two distinct units, with topographical, geological, and land use differences. With regard to the northern area, the Pre-Pyrenees range is a rough mountainous area that reaches 1600 m.a.s.l. Geologically, it is mainly formed by folded and thrusted limestones of the Upper Cretaceous and Middle Eocene, edged in the south by an spectacular ribbon of conglomerate monoliths, the 'mallos' [30]. The area is mostly uninhabited, non-cultivated, 
and mainly covered by thorny shrubs (Genista scorpius and Echinospartum horridum), oaks (Quercus coccifera, Q. ilex, Q. faginea), and pine trees (Pinus halepensis, P. sylvestris and P. nigra). Soils are mostly lithosols, regosols, and calcisols [30].

On the other hand, the southern side is a flat descent from 800 to 400 m.a.s.l., piedmont glacis type. Geologically, it is formed by a sub horizontal alternation of sandstone and clay strata from a huge semiarid alluvial fan of the Miocene Age. Around $50 \%$ of the area is covered by a blanket of Pleistocene gravels until $10 \mathrm{~m}$ depth. Soil types include calcisols, cambisols, and regosols (see Figure S1) [30].

In the Pre-Pyrenees, average temperature is close to $10{ }^{\circ} \mathrm{C}$ and annual rainfall is around $800 \mathrm{~mm}$, while in the piedmont, the average temperature is $12{ }^{\circ} \mathrm{C}$ and the average rainfall is $500 \mathrm{~mm}$.

The piedmont area is mostly covered by dry farming Mediterranean crops ( $80 \%$ barley and $10 \%$ almond, olive trees, and grapes). Barley $\mathrm{N}$ fertilization is divided into two applications: the first one in October, before sowing, usually with $300 \mathrm{~kg} / \mathrm{ha}$ of NPK 15-15-15 fertilizer; and the second one in February, of $150-200 \mathrm{~kg}$ of urea $(46 \% \mathrm{~N})$. Exact values depend on the farmer, and amounts applied should be duly registered in areas administratively declared as vulnerable to water pollution by nitrates [24]. To date, the application of cow manure or pig manure has been minimal in this region, but a strong increase is expected in the coming years because of the construction of new large pig rearing farms. Woody crops, such as almond trees, olive trees, and vines, receive much lower fertilizer doses. Around $10 \%$ of the cultivated area is irrigated land, mostly on the Hoya de Huesca aquifer, historically documented from the 11th century, but without enough water to satisfy the high summer evapotranspiration needs. During the last decades, the irrigated land has been losing its role as a food supply and currently the irrigated areas close to the city of Huesca are mainly dedicated to family gardens and second residences. On the remaining aquifers, there are practically no irrigated areas.

Around 60,000 people live in this area, especially in the city of Huesca and 30 small villages. Several villages tap water from local aquifers with high nitrate levels, often above $50 \mathrm{mg} \cdot \mathrm{L}^{-1}$, exceeding the threshold defined in 98/83/EC [31]. Accordingly, the number of denitrification devices for public water supply facilities is increasing.

\subsection{Hydrogeology}

In the Pre-Pyrenees, there are several karst-type systems, officially grouped in one hydrogeological unit (030 Sinclinal de Jaca-Pamplona). These systems, sparsely studied, are fed by rainwater and, to a lesser extent, by melting snow. GW is discharged by a number of springs to the main river channels and to the southern periphery of the mountains.

In the piedmont area, there are several small free detritic aquifers, recharged by direct rainfall and, locally, by river losses and irrigation. Confederación Hidrográfica del Ebro (CHE, tr. Water Authority of the Ebro Valley) has grouped these aquifers into four units: 091.054 Saso de Bolea-Ayerbe, 091.055 Hoya de Huesca, 091.056 Sasos del Alcanadre, and 091.057 Terrazas del Gállego. Each of them has several subunits, poorly studied. In addition, there is a small aquifer, named Apiés (because of a very small village nearby), not officially defined [26]. Obviously, the administrative limits do not always coincide with the hydrogeological limits.

There are no indications of underground hydraulic connections between the Pre-Pyrenees and the piedmont aquifers. However, four small rivers (viz. Isuela, Sotón, Seco (tr. dry) River in Bolea, and Seco River in Ayerbe) flow from the mountains to the piedmont and feed its aquifers. Isuela River is deeply affected by extractions to irrigate around 2000 ha (by earth ditches and flood irrigation). As the effectiveness of this type of irrigation is low, the extra water also recharges the Hoya de Huesca aquifer. Downstream, the lower reaches of Isuela and Sotón rivers collect the final underground discharge from their respective aquifers. In addition, the Isuela River receives the treated sewage discharge from Huesca (with a population of ca. 50,000 inhabitants) of ca. $24,000 \mathrm{~m}^{3} /$ day.

All the piedmont aquifers are of glacis-type alluvial units formed by limestone gravels, sands, alluvial illitic clays, and quaternary terraces. The detrital cover has a remarkable granulometric heterogeneity, both lateral and vertical, with a maximum thickness of $10 \mathrm{~m}$. The aquifers are mostly 
free, although small areas of semi-confinement have been reported. The impervious base is formed by clay strata with sandstone intercalations, locally with paleo channel geometry.

The Saso de Bolea-Ayerbe aquifer has a surface of $293 \mathrm{~km}^{2}$, and it has, at least, three subunits (but GW divides are not defined). The Hoya de Huesca aquifer unit has an estimated surface area of $2090 \mathrm{~km}^{2}$ [32], and Apiés aquifer has a surface area of $7.9 \mathrm{~km}^{2}$.

Direct recharge by rainfall is estimated at around $20 \%$ of the total rainfall. The Hoya de Huesca aquifer annually recharges around $14 \mathrm{hm}^{3}$ from rainfall and $2 \mathrm{hm}^{3}$ from river losses and irrigation. The saturated zone oscillates year round and rarely has a thickness above $5 \mathrm{~m}$. The general flow of groundwater roughly goes from north to south. Discharge is also very low: the Hoya de Huesca aquifer annually discharges $6.5 \mathrm{hm}^{3}$ by springs, only $0.5 \mathrm{hm}^{3}$ is pumped from shallow wells (for irrigation and water supply, with a maximum depth of $10 \mathrm{~m}$ ), and the rest oozes towards the Isuela River south of Huesca [32,33]. In Saso de Bolea-Ayerbe and Apiés aquifers, pumping is minimal. It is admitted that the average GW residence time in the main aquifers is of the order of one year and that the stored water is of the order of the annual recharge. Maximum transmissivity is of the order of $2 \mathrm{~m} /$ day [34].

No specific studies on aquifer vulnerability have been performed. Nonetheless, the combination of cultivated areas on free aquifers with a shallow water table plus a high permeability of the alluvial deposits, together with the known interconnection between GW and surface water (SW), points to a high pollution vulnerability of the piedmont aquifers.

\subsection{Sampling and Chemical Analyses}

GW $(n=113)$ and SW $(n=31)$ samples of the above-cited aquifers and the related rivers were sampled from 2014 to 2017, according to ISO5667-3 standard [35]. Exact locations of the sampling sites are presented in Table S1. The first phase of the study aimed to cover as many water points as possible, in order to assess the chemical quality of the water (including nitrate concentrations). A second sampling phase, in 21 selected points, was conducted to analyze the monthly evolution of nitrate concentrations from March 2016 to February 2017.

Water temperature and electrical conductivity (EC) were measured in situ with an Orion WTW 3110 (Thermo Scientific, Waltham, MA, USA). All samples were collected in new 2-L PET bottles, stored in coolers, and transported within a period of hours, in the sampling day, to the Analytic Chemistry laboratories of the Escuela Politécnica Superior (University of Zaragoza). pH was determined upon arrival of the samples with an Orion Star A111 benchtop pH meter. Following APHA et al. [36] and ISO 3696-1987 [37] standards, alkalinity was determined by $\mathrm{HCl}$ titration, chloride by the Mohr method, sulfate by turbidimetry of $\mathrm{BaSO}_{4}$, and sodium, potassium, and calcium by flame atomic absorption spectrometry on a Varian Spectra Aa 1110. Magnesium was determined by atomic absorption in the same instrument. Nitrate was determined by UV molecular absorption spectrometry, at $220 \mathrm{~nm}$, after acidification, with an ATI Unicam V2 apparatus.

\subsection{Statistical Analysis}

Principal component analysis (PCA), with the Varimax rotation method with Kaiser normalization, was carried out with IBM (Armonk, NY, USA) SPSS Statistics v.22 software. In the PCA, the components that accounted for most of the variance were selected, and those that contained only a small percentage of the variance of the original data were removed.

\section{Results and Discussion}

\subsection{Spatial Hydrochemistry of the Waters}

Table S1 presents the results of the areal sampling. Hydrochemical data were in the usual ranges in the area, with abundant calcium carbonate. Figure 2 presents the box plot of hydrochemical data for groundwater (top) and surface water samples (bottom). As expected, surface water temperature was directly related with the seasonal and diurnal changes of temperature. On the other hand, GW 
water temperatures were usually close to the annual average temperature, i.e., close to $10{ }^{\circ} \mathrm{C}$ in the Pre-Pyrenees and $12{ }^{\circ} \mathrm{C}$ in the piedmont. However, important outliers were found, explained by several reasons: for instance, a weak hydrothermal spring $\left(19^{\circ} \mathrm{C}\right)$ in the Pre-Pyrenees was included in the study (UTM coordinates $30 \mathrm{~N} X=712,291, \mathrm{Y}=4,685,412$ ).
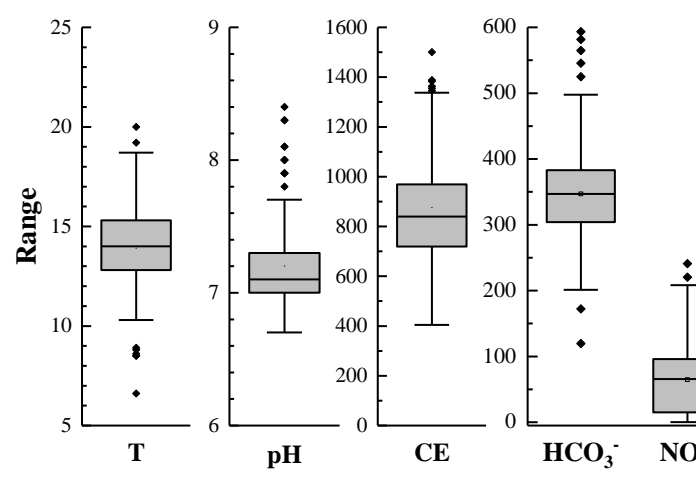

\section{Groundwater}
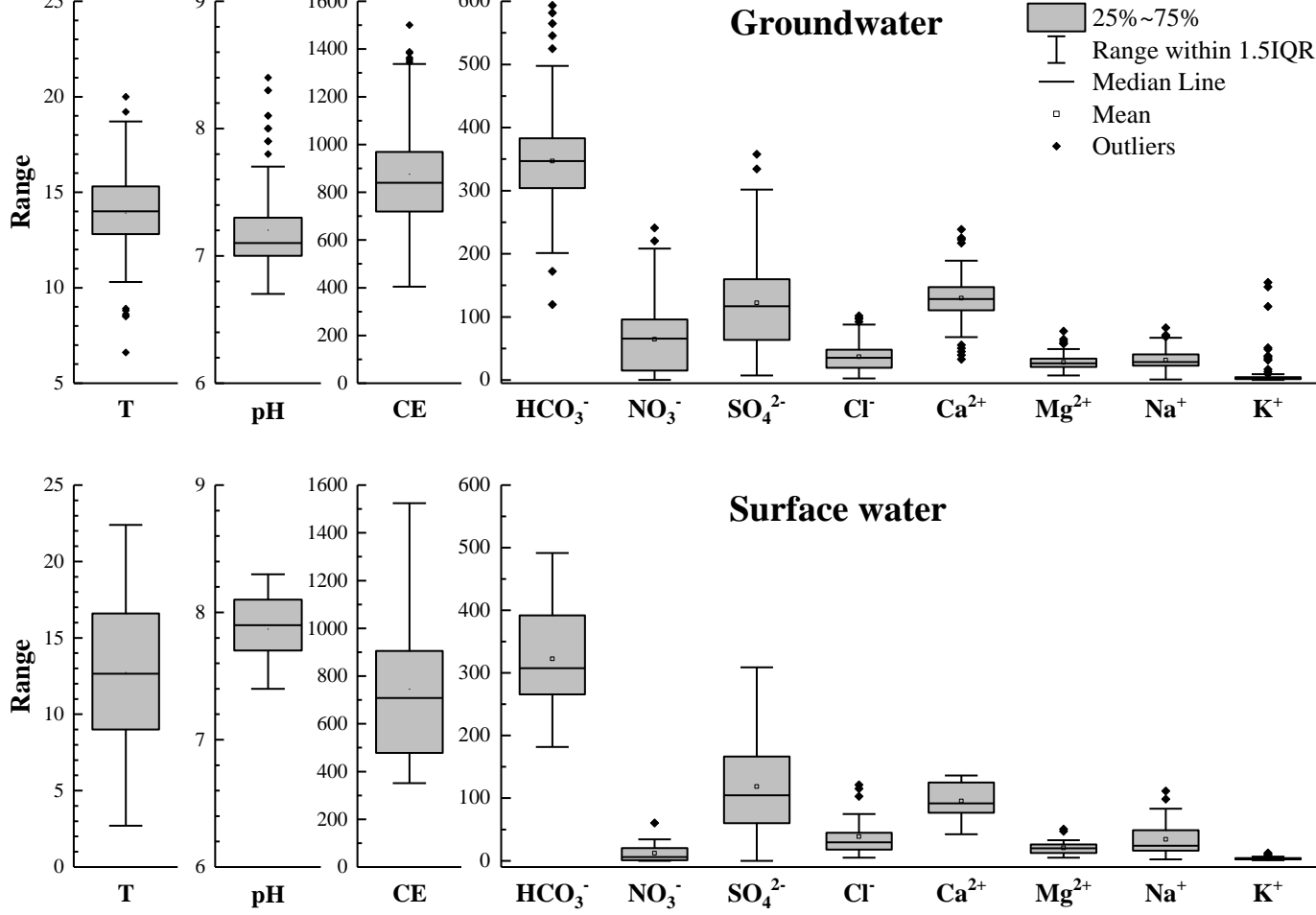

Surface water

Figure 2. Box plot of hydrochemical data for groundwater samples (top) and surface water samples (bottom).

In GW and SW of both areas, $\mathrm{pH}$ values ranged from 6.8 to 8.4. These are normal values for water rich in calcium carbonate. EC was quite constant in SW and GW of the Pre-Pyrenees, with values close to $450 \mu \mathrm{S} / \mathrm{cm}$ at $20{ }^{\circ} \mathrm{C}$, although some springs had higher values, indicating the presence of evaporites (Keuper fm. Trias) in thrust faults. In the aquifers of the piedmont, EC for SW and GW samples was higher than in the northern area and increased towards the south, in the direction of SW and GW flow, due to the southward increasing presence of evaporites in the Miocene geologic materials. By that reason, while all the SW and GW of the Pre-Pyrenees were of calcium bicarbonate type, in the piedmont there a north-south trend from calcium carbonate water type toward calcium bicarbonate-sulfate type was observed.

Mean hydrogencarbonate values were very similar in GW and SW (344 and $323 \mathrm{mg} \cdot \mathrm{L}^{-1}$, respectively) and would be controlled by the dissolution of calcium carbonate. Mean calcium ion content was not significantly different between SW and GW (128 and $85 \mathrm{mg} \cdot \mathrm{L}^{-1}$, respectively). The values in the GW of aquifers of piedmont increased to the south by the presence of gypsum south of Huesca. Accordingly, sulfate ion contents also increased to the south. Chloride, magnesium, and sodium showed similar values. As expected, the average values of potassium in SW samples was noticeably smaller than the $\mathrm{Na}^{+}$content, usually of the order of $10 \%$, due to the normal uptake by plant roots. However, $\mathrm{K}^{+}$values in $\mathrm{GW}$ showed a large number of outliers, out of which several could be identified as cases of contamination by agricultural pollution or by domestic wastewater. Nonpoint source pollution and uptake by plants would explain the strong differences in the median values of nitrates between GW $\left(65 \mathrm{mg} \cdot \mathrm{L}^{-1}\right)$ and SW $\left(12 \mathrm{mg} \cdot \mathrm{L}^{-1}\right)$. Evidently, nitrates need a subsequent specific study. 


\subsection{Principal Component Analysis}

A PCA analysis was performed on all GW hydrochemical data, obtaining three components that explained $72.86 \%$ of the variance (Figure 3 ). Two of them were related to natural mineralization of water: the strongest underlying trend in the feature set (component 1) was related to the most soluble natural salts (viz. chloride, sulfate, and sodium) and that the second strongest underlying trend (component 2) was associated with calcium, magnesium, and hydrogencarbonates, related with limestone dissolution. Electrical conductivity appeared in both components, as expected. The third strongest underlying trend (component 3), was related to nitrates and potassium and would have an anthropogenic origin, associated with agricultural fertilization and domestic wastewater. Correlations between the main groundwater ions and electrical conductivity are summarized in Table S2.

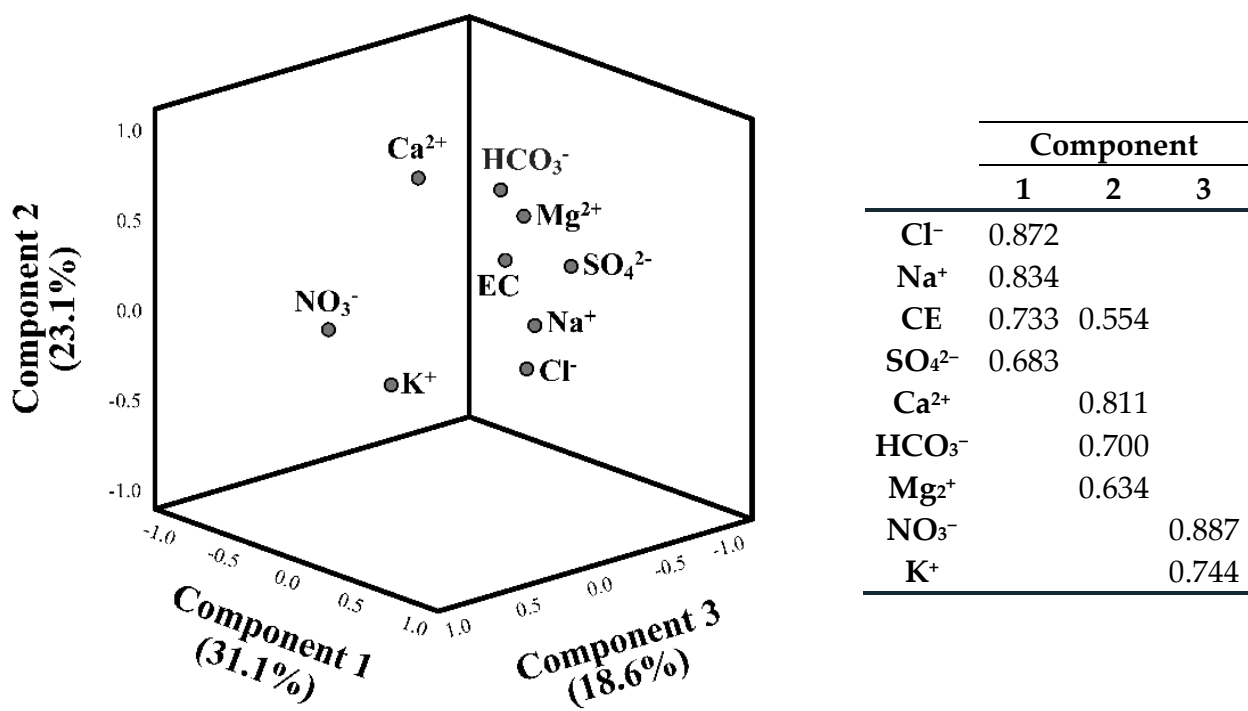

Figure 3. Principal Component Analysis (PCA) component plot in rotated space (left) and rotated component matrix (right). Percentages below the components indicate the percentage of variance explained.

\subsection{GW and SW Nitrate Content}

As discussed above, there was a clear difference in nitrate content in GW between the Pre-Pyrenees and the piedmont aquifers. In the hilly area, the nitrate content of its springs was of the order of $5 \mathrm{mg} \cdot \mathrm{L}^{-1}$ or less, similar to those reported in other areas, e.g., the Piemonte (Northern Italy) [38]. These values are natural, given that the recharge area is covered by natural vegetation, without cropped fields, human settlements, animal farms, or open ranch livestock. On the contrary, in the piedmont area, the $\mathrm{N}$ level in GW was clearly higher, reaching values of $200 \mathrm{mg} \cdot \mathrm{L}^{-1}$.

Figure 4 summarized the nitrate contents in the sampling points covered in this study. The wide range of concentrations points to a clear hydrochemical complexity, with the lowest nitrate values in the karstic aquifers of the Pre-Pyrenees and in the rivers in the west part of Hoya de Huesca, and the highest concentrations in the GW from the flatland aquifers.

Field information and Figure 4 suggest a relationship between nitrate contents in GW and land use. Figure 5 shows clear differences between dry farming and irrigated areas in terms of nitrate content in GW: GW under dry farming areas shows contents over $100 \mathrm{mg} \cdot \mathrm{L}^{-1}$, suggesting a relation with $\mathrm{N}$ fertilization of winter crops. Conversely, irrigated areas present lower values of $\mathrm{N}$. It may be hypothesized that this is due, on the one hand, to the lower use of $\mathrm{N}$ fertilizer in family orchards, and, on the other hand, to the use of irrigation water from the Isuela River (whose water with low nitrate contents would dilute the nitrates in GW). 


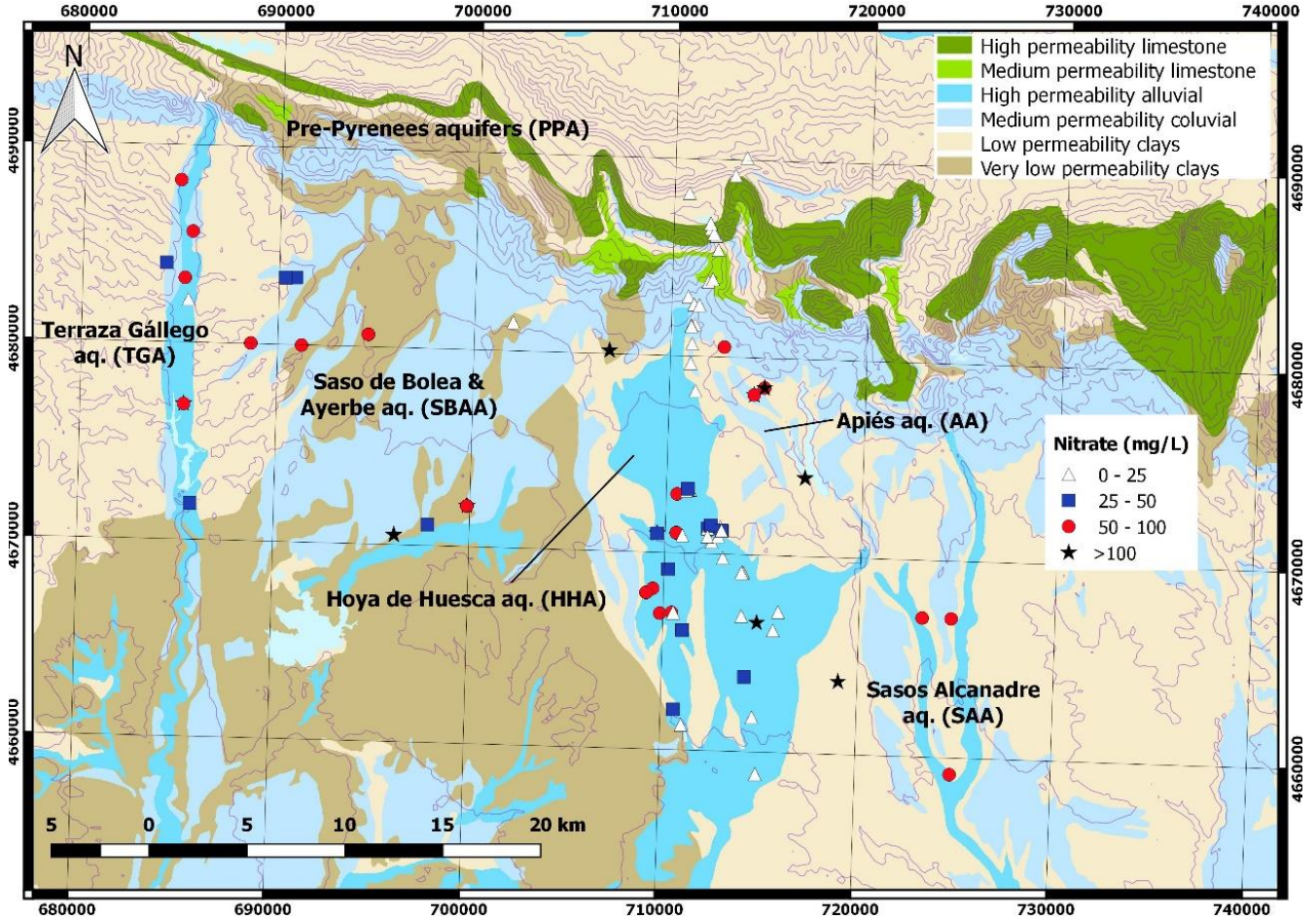

Figure 4. Spatial distribution of nitrate contents in the studied aquifers on a Spanish Geological Survey (IGME) map of Spanish aquifers [32].

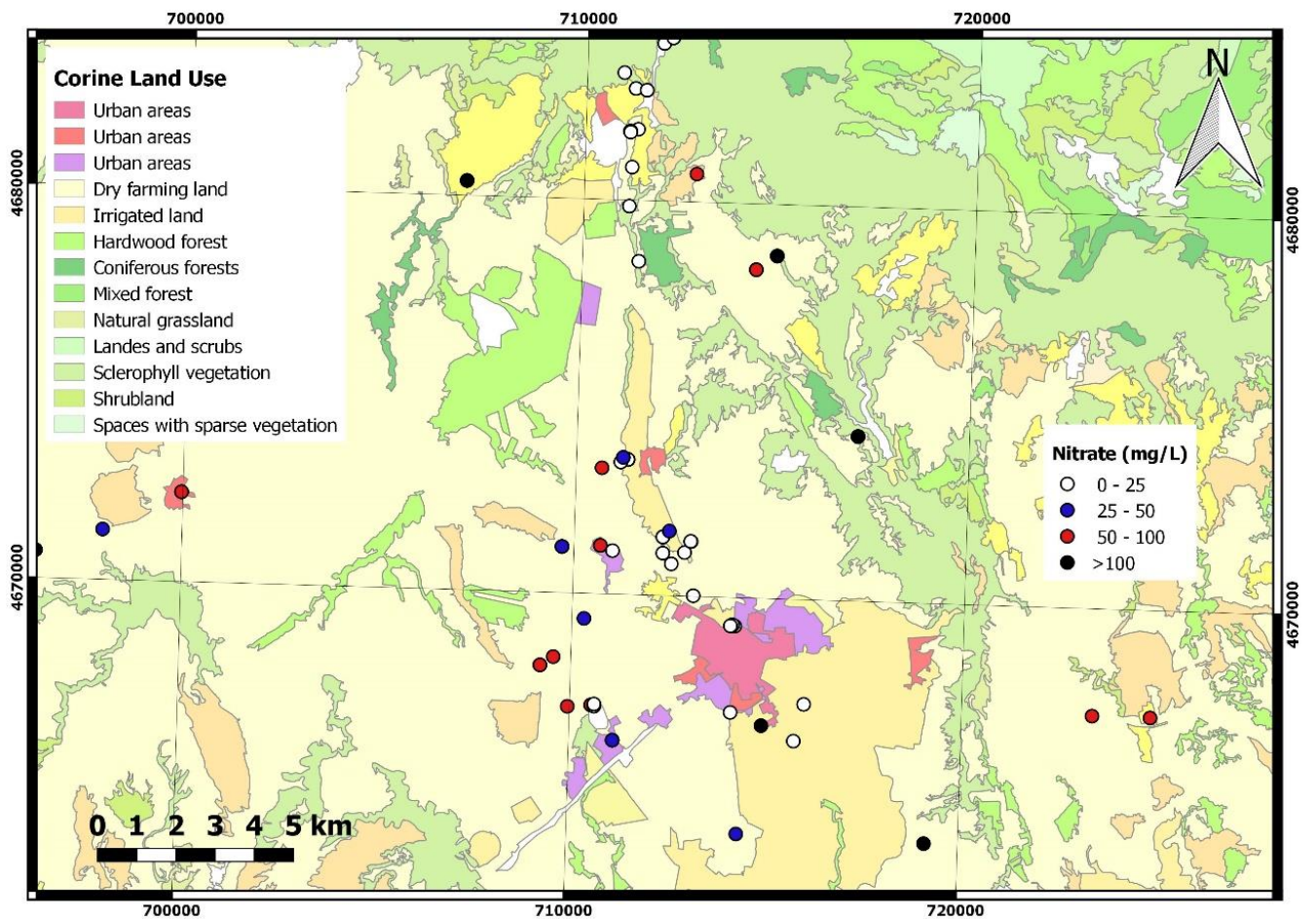

Figure 5. Nitrate contents in groundwater and land use in the Hoya de Huesca aquifer on a CORINE land cover (EEA) layer. Irrigated areas around Huesca city, in the center of the figure, do not have enough water for crops like maize and lucerne.

In order to compare the results reported herein with those reported for aquifers in other regions, it is necessary to restrict the scope to Mediterranean areas with similar agro climatic conditions and crops. In the Mediterranean environment, water is scarce in the summer and limits yield. By this 
reason, irrigation has been widely implemented from ancient times. The results presented in this study differ from those reported for neighboring areas with Mediterranean crops, in which nitrate pollution is associated with irrigated crops, as fertilization is coupled with water application to obtain high agronomical and economical profits $[13,17,18,39,40]$. This was not the case in the present study for several reasons. Firstly, the irrigated areas do not have enough water to allow cash crops as maize or lucerne. Secondly, the irrigated plots are small and mostly used as orchards or, more recently, as gardens of peri-urban holiday homes. On the contrary, dry farming areas have larger fields, more suitable for the use of modern machinery, and support winter crops, well adapted to the local Mediterranean climate with rainy periods at fall and spring and a hot and dry summer. High $\mathrm{N}$ mineral fertilization application rates and the low efficiency in nitrate uptake by the crops would be responsible for lixiviation toward the GW table, notwithstanding episodes of rainfall and drought, which would also play an important role in the movement of water through the soil profile.

As noted above, clear differences in nitrate contents were observed between SW and GW samples. The surface waters of the Pre-Pyrenees, mainly studied in the Isuela River watershed, showed low nitrate contents, of the order of $5 \mathrm{mg} \cdot \mathrm{L}^{-1}$ or lower. Entering the piedmont, some rivers like Seco River in Bolea and Seco River in Ayerbe usually discharge most of their water to the aquifers. Only the Isuela River keeps some water, although it is usually completely tapped for irrigation. Downstream, the main rivers, i.e., Isuela River and Sotón River, receive water from the lower part of the corresponding aquifers and their discharge and nitrate content increases. In addition, the Isuela River collects the discharge of the sewage treatment plant of Huesca city. In short, the evolution of the nitrate concentrations in the rivers and alluvial aquifers showed a tendency to increase from the headwaters to the lower courses, in the same line presented by $[39,40]$.

\subsection{Temporal Evolution of Nitrate Contents}

As the general results of the spatial analysis showed a widespread nitrate pollution in dry farming areas, some questions about the temporal evolution of nitrates in GW, both in the short term and in the long term, remained open.

\subsubsection{Short Term Evolution}

As indicated in Section 2.3, $21 \mathrm{GW}$ points were selected to study the evolution of GW quality over 12 consecutive months, from March 2016 to February 2017. Figure 6 shows the evolution of nitrate concentration. While a clear temporal stability in the evolution of the nitrate content was observed in the points with low nitrate concentrations, a quite strong variability was detected in points with nitrate contents $\geq 100 \mathrm{mg} \cdot \mathrm{L}^{-1}$. Three factors may be considered: crops, fertilization, and rainfall. Crops and fertilization doses, which depend on the farmers' choices, may change over time and are not always easy to know. As the $\mathrm{N}$ fertilizer was applied from October to February, some water sampling points seemed to respond very quickly, thus confirming the vulnerability of the aquifer. The decrease in the summer period in some aquifers (e.g., $30 \mathrm{~N} \mathrm{X}=717,047, \mathrm{Y}=4,673,973$; and 30N $X=699,856, Y=4,672,064)$ may be explained by fast leaching or denitrification after post-harvest season, as suggested by Juntakut et al. [11]. Other points showed a clear delay and some had unexpected behaviors. For instance, one of the points with the highest nitrate concentrations (30N X $=696,174$, $Y=4,670,492$ ) showed steadily increasing values during the year of study, while another point showed a final fast rise that cannot be explained with the available data $(30 \mathrm{~N} \mathrm{X}=709,868, \mathrm{Y}=4,680,163)$. 

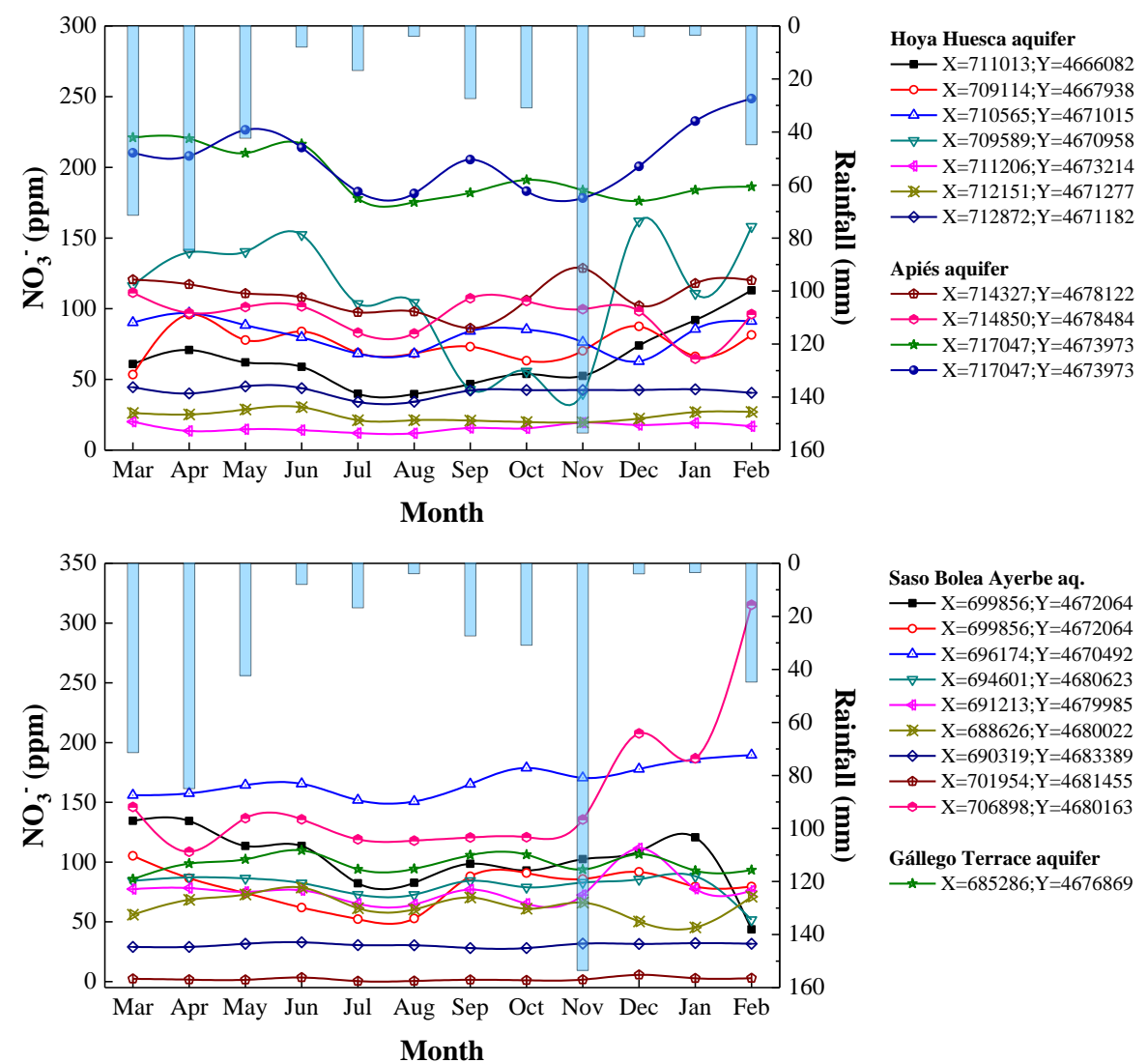

Saso Bolea Ayerbe aq

$\rightarrow-X=699856 ; Y=467206$

$\multimap-X=699856 ; Y=4672064$ $\triangle-\mathrm{X}=696174 ; \mathrm{Y}=4670492$ $\neg-\mathrm{X}=694601 ; \mathrm{Y}=4680623$ $\because-X=691213 ; Y=4679985$ $\mathrm{X}=688626 ; \mathrm{Y}=4680022$ - $X=688626 ; Y=4680022$ $\sim X=690319 ; Y=4683389$ $\rightarrow \mathrm{X}=701954 ; \mathrm{Y}=4681455$ $\rightarrow X=706898 ; Y=4680163$

Gállego Terrace aquifer $\star-X=685286 ; Y=4676869$

Figure 6. Nitrate content evolution in selected GW sampling points in Hoya de Huesca, Saso de Bolea-Ayerbe, Apiés, and Gállego Terrace aquifers form March 2016 until February 2017. Note that the vertical scale is different in the two plots. All coordinates in the legend refer to UTM zone 30N.

Previous rainfall is an important factor in decision making for farmers in semi-arid areas. For instance, after a drought period, farmers may reduce the fertilization applied in February; on the contrary, that dose may be increased if the winter has been wet and it is assumed than fertilization applied in autumn may have been leached. Table 1 shows rainfall data from the city of Huesca in 2016 $(589 \mathrm{~mm})$ and $2017(389 \mathrm{~mm})$, where the variability of a semi-arid climate is evident. In addition to the strong variation in total annual rainfall, it can be observed that November 2016 was a very rainy month by local standards, and this can contribute to the rapid responses of some water sampling points mentioned above.

Table 1. Rainfall (in mm) in Huesca in 2016 and 2017.

\begin{tabular}{|c|c|c|c|c|c|c|c|c|c|c|c|c|}
\hline Month & Jannuary & February & March & April & May & June & July & August & Septmeber & October & November & December \\
\hline 2016 & 31.4 & 114.5 & 71.4 & 85.0 & 42.4 & 8.0 & 16.8 & 3.9 & 27.4 & 30.9 & 153.6 & 4.0 \\
\hline 2017 & 3.5 & 44.8 & 78.4 & 17.6 & 38.5 & 91.1 & 1.7 & 22.6 & 19.3 & 32.9 & 3.9 & 34.8 \\
\hline
\end{tabular}

The results show the complexity of the hydrologic behavior of these small and shallow aquifers and the necessity of future specific studies. This complex behavior between the different GW points has been also observed in a similar study conducted on an aquifer polluted by pig slurry [41].

\subsubsection{Long Term Evolution}

To evaluate the long-range temporal evolution of nitrates, all the data obtained since 1994 from selected points of the county has been compiled from published [25-29] and unpublished results. Nitrate contents, presented in Figure 7, have been organized into groups depending on the aquifer. It becomes apparent than the points with low nitrate levels are stable over time, whereas the points with 
high levels, that have remained high for more than two decades, show variable behaviors. The results signal an old problem and provide some evidence on failures in the implementation of the best management practices prescribed by Nitrate Directive 1991/676/EEC, in line with the findings in other parts of the Mediterranean [42,43].
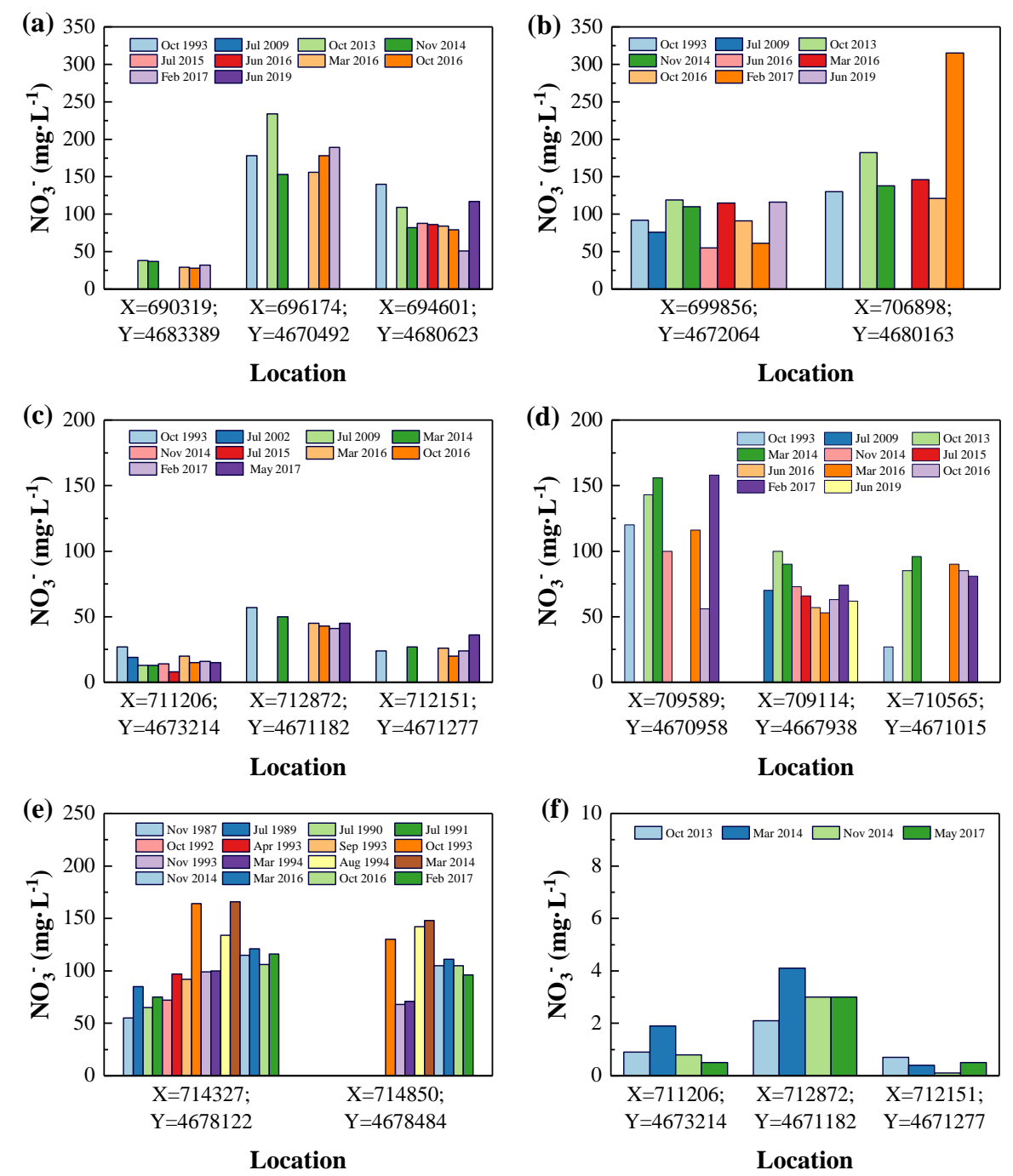

Figure 7. Historical evolution of nitrate concentration in the western side of Hoya de Huesca County, from reports by several authors [25-29,32,33], academic works, and unpublished official health reports. $(\mathbf{a}, \mathbf{b})$ Saso Bolea Ayerbe aquifer; (c,d) Hoya Huesca aquifer; (e) Apiés aquifer; (f) Pre-Pyrenees aquifer. Note: $y$-axis scales are different for each aquifer. All coordinates in the x-axes labels refer to UTM zone $30 \mathrm{~N}$.

\section{Conclusions}

The presence of high levels of nitrate in groundwater in the aquifers of the west part of Hoya de Huesca County, which affects the water supply of several small villages, has been attested and a relationship with land use has been suggested, although further hydrological studies would be needed. The highest nitrate levels appeared in dry farming areas in which winter cereal is grown (with concentrations $>200 \mathrm{mg} \cdot \mathrm{L}^{-1}$ ), in contrast with irrigated areas, probably due to the use of low nitrate-containing surface water in family orchards and small gardens of weekend houses. With regard to nitrate content short-term evolution, a 12-month monitoring carried out between 2016 and 2017 for 21 selected sampling points showed an annual regularity in the points with low nitrate levels, and a pattern that mimicked fertilizer application schedules in some of the most polluted points. 
However, the evolution of others points was not easily explainable and will require specific agronomic and hydrogeological research. In relation to long-range evolution, the compilation of data for 16 selected points from published papers and unpublished reports since 1990 showed that the problem is old and that pollution control measures arising from Council Directive 1991/676/EEC have not been successful.

Supplementary Materials: The following are available online at http://www.mdpi.com/2073-4395/10/1/22/s1, Table S1: Hydrochemical data of water samples from surface (SW) and aquifers (GW) in the western side of the Hoya de Huesca County (Spain), Table S2: Correlation matrix between main groundwater ions and electrical conductivity, Figure S1: Geological map of the area of study, according to Spanish Geological Survey's (IGME) GEODE-Continuous digital geological map of Spain color code.

Author Contributions: Conceptualization, R.Z. and J.A.C.; methodology, R.Z. and J.A.C.; validation, J.A.C.; formal analysis, R.Z., P.M.-R., and J.A.C.; investigation, R.Z. and J.A.C.; resources, J.A.C.; writing-original draft preparation, R.Z., P.M.-R., and J.A.C.; writing-review and editing, P.M.-R., and J.A.C.; visualization, P.M.-R.; supervision, J.A.C. All authors have read and agreed to the published version of the manuscript.

Funding: This research received no external funding.

Acknowledgments: The authors wish to thank to all the students, laboratory technicians, mayors and local population involved in the works that conducted present paper. Rainfall data has been provided by the Irrigation Office of Aragon Government (DGA). We thank the two anonymous reviewers whose comments/suggestions have helped to improve and clarify this manuscript.

Conflicts of Interest: The authors declare no conflict of interest.

\section{References}

1. Weih, M. A Calculation Tool for Analyzing Nitrogen Use Efficiency in Annual and Perennial Crops. Agronomy 2014, 4, 470-477. [CrossRef]

2. Agneessens, L.; De Waele, J.; De Neve, S. Review of Alternative Management Options of Vegetable Crop Residues to Reduce Nitrate Leaching in Intensive Vegetable Rotations. Agronomy 2014, 4, 529-555. [CrossRef]

3. Montemurro, F.; Diacono, M. Towards a Better Understanding of Agronomic Efficiency of Nitrogen: Assessment and Improvement Strategies. Agronomy 2016, 6, 31. [CrossRef]

4. Herrera, J.; Rubio, G.; Häner, L.; Delgado, J.; Lucho-Constantino, C.; Islas-Valdez, S.; Pellet, D. Emerging and Established Technologies to Increase Nitrogen Use Efficiency of Cereals. Agronomy 2016, 6, 25. [CrossRef]

5. Bijay, S.; Yadvinder, S.; Sekhon, G.S. Fertilizer-N use efficiency and nitrate pollution of groundwater in developing countries. J. Contam. Hydrol. 1995, 20, 167-184. [CrossRef]

6. Chen, S.; Wu, W.; Hu, K.; Li, W. The effects of land use change and irrigation water resource on nitrate contamination in shallow groundwater at county scale. Ecol. Complex. 2010, 7, 131-138. [CrossRef]

7. Kim, H.-S.; Park, S.-R. Hydrogeochemical Characteristics of Groundwater Highly Polluted with Nitrate in an Agricultural Area of Hongseong, Korea. Water 2016, 8, 345. [CrossRef]

8. Livingston, M.L.; Gory, D.C. Agricultural Nitrate Contamination of Ground Water: An Evaluation of Environmental Policy. J. Am. Water Resour. Assoc. 1998, 34, 1311-1317. [CrossRef]

9. Babiker, I. Assessment of groundwater contamination by nitrate leaching from intensive vegetable cultivation using geographical information system. Environ. Int. 2004, 29, 1009-1017. [CrossRef]

10. Gu, B.; Ge, Y.; Chang, S.X.; Luo, W.; Chang, J. Nitrate in groundwater of China: Sources and driving forces. Glob. Environ. Chang. 2013, 23, 1112-1121. [CrossRef]

11. Juntakut, P.; Snow, D.D.; Haacker, E.M.K.; Ray, C. The long term effect of agricultural, vadose zone and climatic factors on nitrate contamination in Nebraska's groundwater system. J. Contam. Hydrol. 2019, 220, 33-48. [CrossRef] [PubMed]

12. Strebel, O.; Duynisveld, W.H.M.; Böttcher, J. Nitrate pollution of groundwater in western Europe. Agric. Ecosyst. Environ. 1989, 26, 189-214. [CrossRef]

13. Sacchi, E.; Pilla, G.; Gerbert-Gaillard, L.; Zuppi, G. A regional survey on nitrate contamination of the Po valley alluvial aquifer (Northern Italy). In Proceedings of the International Symposium on Advances in Isotope Hydrology and its Role in Sustainable Water Resources Management (IHS-2007), Vienna, Austria, 21-25 May 2007; International Atomic Energy Agency-Isotope Hydrology Section: Vienna, Austria, 2007; p. 471. 
14. Hansen, B.; Dalgaard, T.; Thorling, L.; Sørensen, B.; Erlandsen, M. Regional analysis of groundwater nitrate concentrations and trends in Denmark in regard to agricultural influence. Biogeosciences 2012, 9, 3277-3286. [CrossRef]

15. European Commission. Council Directive 91/676/EEC of 12 December 1991 Concerning the Protection of waters Against Pollution Caused by Nitrates from Agricultural Sources; European Commission: Brussels, Belgium, 1991; pp. 1-8.

16. European Commission. Directive 2000/60/EC of the European Parliament and of the Council of 23 October 2000 Establishing a Framework for Community Action in the Field of Water Policy; European Commission: Brussels, Belgium, 2000.

17. Arauzo, M.; Martínez-Bastida, J.J. Environmental factors affecting diffuse nitrate pollution in the major aquifers of central Spain: Groundwater vulnerability vs. groundwater pollution. Environ. Earth Sci. 2015, 73, 8271-8286. [CrossRef]

18. Arauzo, M.; Valladolid, M. Drainage and N-leaching in alluvial soils under agricultural land uses: Implications for the implementation of the EU Nitrates Directive. Agric. Ecosyst. Environ. 2013, 179, 94-107. [CrossRef]

19. Hódar-Pérez, A.; López-Chicano, M.; Calvache Quesada, M.L.; Sánchez Úbeda, J.P.; Martín-Montañés, C. Evolución del contenido en nitratos en el acuífero de Motril-Salobreña druante la década 2001-2011. In Proceedings of the SIAGA 2015. El Agua, Clave Medioambiental y Socioeconómica, Malaga, Spain, 4 November 2015; Instituto Geológico y Minero de España Málaga: Madrid, Espanha, 2015; pp. 1-11.

20. Martínez-Bastida, J.J.; Arauzo, M.; Valladolid, M. Intrinsic and specific vulnerability of groundwater in central Spain: The risk of nitrate pollution. Hydrogeol. J. 2009, 18, 681-698. [CrossRef]

21. Arauzo, M.; Valladolid, M.; Martínez-Bastida, J.J. Spatio-temporal dynamics of nitrogen in river-alluvial aquifer systems affected by diffuse pollution from agricultural sources: Implications for the implementation of the Nitrates Directive. J. Hydrol. 2011, 411, 155-168. [CrossRef]

22. García-Garizábal, I.; Causapé, J.; Abrahao, R. Nitrate contamination and its relationship with flood irrigation management. J. Hydrol. 2012, 442-443, 15-22. [CrossRef]

23. Barros, R.; Isidoro, D.; Aragüés, R. Irrigation management, nitrogen fertilization and nitrogen losses in the return flows of La Violada irrigation district (Spain). Agric. Ecosyst. Environ. 2012, 155, 161-171. [CrossRef]

24. Diputación General de Aragón. ORDEN DRS/882/2019, de 8 de Julio, por la que se Designan y Modifican las Zonas Vulnerables a la Contaminación de las Aguas por Nitratos Procedentes de Fuentes Agrarias en la Comunidad Autónoma de Aragón; Aragón, D.G.D., Ed.; Diputación General de Aragón: Zaragoza, Spain, 2019; pp. 21487-21494.

25. Cuchí Oterino, J.A.; Díaz Ara, R.C.; Larrey, O.; Lasaosa, J.C. Niveles de ión nitrato en aguas subterráneas de la Hoya de Huesca. Kalium Rev. Ing. Ind. Esc. Univ. Politécnica Huesca 1997, 4, 117-128.

26. Cuchí Oterino, J.A.; Gimeno Cuenca, Y. Contaminación por nitratos en el acuífero de Apiés (Huesca). Geórgica Rev. Espac. Rural. 1997, 5, 59-72.

27. Zufiaurre Galarza, R.; Traba, L.; Cuchí Oterino, J.A. Caracterización hidroquímica de aguas de la hoya de Huesca. Lucas Mallada Rev. Cienc. 2015, 17, 17-44.

28. Zufiaurre Galarza, R.; Gracia, Ó.; Cuchí Oterino, J.A. Evolución del contenido en nitratos en aguas subterráneas de la Hoya de Huesca (marzo de 2016-febrero de 2017). Lucas Mallada Rev. Cienc. 2017, 19, 185-207.

29. Sampietro, H.; Zufiaurre Galarza, R.; López Flores, R.; Cuchí Oterino, J.A. Estudio hidroquímico del río Isuela (Huesca). Lucas Mallada Rev. Cienc. 2018, 20, 219-250.

30. Teixell, A.; García-Sansegundo, J. Mapa Geológico de España, Escala 1:50,000-Uesca; Instituto Geológico y Minero de España: Madrid, Spain, 2014; p. 32.

31. European Commission. Council Directive 98/83/EC of 3 November 1998 on the Quality of Water Intended for Human Consumption; European Commission: Brussels, Belgium, 1998; p. 23.

32. Instituto Geológico y Minero de España. Encomienda de Gestión Para la Realización de Trabajos Científico-Técnicos de Apoyo a la Sostenibilidad y Protección de las Aguas Subterráneas. Actividad 4: Identificación y Caracterización de la Interrelación que se Presenta entre Aguas Subterráneas, Cursos Fluviales, Descargas por Manantiales, Zonas Húmedas y Otros Ecosistemas Naturales de Especial Interés Hídrico, Gobierno de España-Ministerio de Ciencia e Innovación; Ministerio de Medio Ambiente y Medio Rural y Marino: Madrid, Spain, 2007; p. 279.

33. CHE. Aguas Afectadas por Nitratos de Origen Agrario (2012-2015). Available online: http://chebro.es/ contenido.visualizar.do?idContenido=19441\&idMenu=3811 (accessed on 26 November 2019). 
34. CHE. Informe Piezométro de Huesca: 090.055.001; Confederación Hidrográfica del Ebro: Zaragoza, Spain, 2012; p. 83.

35. International Organization for Standardization. ISO 5667-3:2018. Water Quality-Sampling-Part 3: Preservation and Handling of Water Samples; International Organization for Standardization: Geneva, Switzerland, 2018; p. 52.

36. American Pharmacists Association, American Water Works Association, The World Economic Forum. Standard Methods for Examination of Water and Wastewater, 22th ed.; American Public Health Association: Washington, DC, USA, 2012; p. 1360.

37. International Organization for Standardization. ISO 3696:1987. Water for Analytical Laboratory Use-Specification and Test Methods; International Organization for Standardization: Geneva, Switzerland, 1987; p. 5.

38. Debernardi, L.; De Luca, D.A.; Lasagna, M. Correlation between nitrate concentration in groundwater and parameters affecting aquifer intrinsic vulnerability. Environ. Geol. 2007, 55, 539-558. [CrossRef]

39. Sarmanho Lima, A. Origen de la Contaminación por Nitratos en la Masa de Agua Subterránea del Campo de Montiel; Universidad Autónoma de Madrid: Madrid, Spain, 2008.

40. Karyotis, T.; Panagopoulos, A.; Pateras, D.; Panoras, A.; Danalatos, N.; Angelakis, C.; Kosmas, C. The Greek Action Plan for the mitigation of nitrates in water resources of the vulnerable district of Thessaly. J. Mediterr. Ecol. 2002, 3, 77-83.

41. Boy-Roura, M.; Menció, A.; Mas-Pla, J. Temporal analysis of spring water data to assess nitrate inputs to groundwater in an agricultural area (Osona, NE Spain). Sci. Total Environ. 2013, 452-453, 433-445. [CrossRef]

42. Izcara Palacios, S.P. La directiva nitratos en España (el ejemplo del Campo de Dalías, Almería). Rev. Española Estud. Agrosoc. Pesq. 2000, 186, 203-226.

43. Nguyen, T.P.L.; Seddaiu, G.; Roggero, P.P. Hybrid knowledge for understanding complex agri-environmental issues: Nitrate pollution in Italy. Int. J. Agric. Sustain. 2013, 12, 164-182. [CrossRef]

(C) 2019 by the authors. Licensee MDPI, Basel, Switzerland. This article is an open access article distributed under the terms and conditions of the Creative Commons Attribution (CC BY) license (http://creativecommons.org/licenses/by/4.0/). 